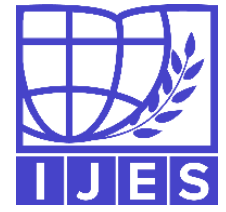

Article History Received: 10.01 .2021 Accepted: 20.02.2021 Published: 30.03 .2021
International Journal of Education and Science print ISSN: 2618-0553; online ISSN: 2618-0561; DOI: 10.26697/ijes Journal Website: https://ijes.world

SOCIAL AND BEHAVIORAL SCIENCES

Economics

REVIEW RESEARCH

\section{Principles of Digitalisation of the State Economy}

\author{
Iryna S. PYPENKO ${ }^{1,2,3,4^{*}} \mathbb{D}$, Yuriy B. MELNYK ${ }^{2,3} \mathbb{C}$
}
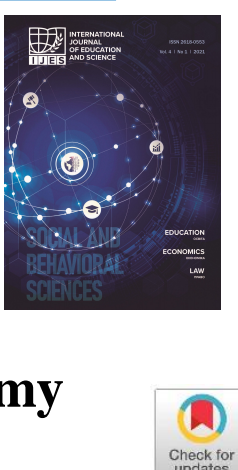

\footnotetext{
${ }^{1}$ Simon Kuznets Kharkiv National University of Economics, Ukraine

${ }^{2}$ Kharkiv Regional Public Organization "Culture of Health” (KRPOCH), Ukraine

${ }^{3}$ Scientific Research Institute KRPOCH, Ukraine

${ }^{4}$ Educational Center KRPOCH, Ukraine

* Corresponding Author's Email: iryna.pypenko@hneu.net
}

\author{
Принципи цифровізації економіки держави \\ Пипенко І. С. ${ }^{1,2,3,4}$, Мельник Ю. Б. ${ }^{2,3}$ \\ ${ }^{1}$ Харківський наиіональний економічний університет імені Семена Кузнеия, Украӥна \\ ${ }^{2}$ Харківська обласна громадська організація “Культура Здоров'я” (ХОГОКЗ), Украйна \\ ${ }^{3}$ Науково-дослідний інститут ХОГОКЗ, Україна \\ ${ }^{4}$ Освітній центр ХОГОКЗ, Украӥна
}

\author{
Принципы цифровизации экономики государства \\ Пипенко И. С. ${ }^{1,2,3,4}$, Мельник Ю. Б. ${ }^{2,3}$ \\ ${ }^{1}$ Харьковский национальный экономический университет имени Саймона Кузнеца, Украина \\ ${ }^{2}$ Харьковская областная общественная организаџия “Культура Здоровья” (ХОГОКЗ), Украина \\ ${ }^{3}$ Научно-исследовательский институт ХОГОКЗ, Украина \\ ${ }^{4}$ Образовательный иентр ХОГОКЗ, Украина
}

\begin{abstract}
Background: The digitalisation of the world economy as a means of improving the quality of human life is becoming increasingly important. The essence of the digital economy is multifaceted and insufficiently studied, in particular, the concept of "digital economy" needs to be clarified, the principles for digitalisation of the economy for specific countries and ways to implement them need justification.

Purpose: To explore the current trends for digitalisation of the world economy and on this basis to develop principles and ways to implement them at the state level.

Materials and Methods: A set of theoretical methods was used: analysis of academic literature, current normative documents and draft legislative acts, as well as synthesis, comparison, generalization, systematization to define and substantiate the guiding principles for digitalisation of the economy and ways to implement them in Ukraine.

Results: Current trends in the digitalisation of the world economy were studied. The essence of the concept of "digital economy" was clarified. We propose to understand the digital economy as a type of economic activity in the system of socio-behavioral and cultural relations with the use of digital technologies, characterized by the creation, collection, processing, storage, transfer and use of digitized resources. The guiding principles for digitalisation of the economy were justified: integrity, phasing, leading, innovation, adaptability, simplicity (accessibility). Ways of implementation were developed for each principle. They contain answers to key questions: what needs to be done? how to stimulate? what support should be provided by the state?

Conclusions: This paper reveals the current trends of digitalisation of the world economy and provides responsible persons, who determine the country policy, the guiding principles for defining and implementing digitalisation strategies in the most appropriate sectors of the economy at the state level.
\end{abstract}

Keywords: digital economy, digitalisation, digitisation, principles of digitalisation, ways to implement the principles.

DOI: https://doi.org/10.26697/ijes.2021.1.5 JEL: O11, O14, O38 UDC: 330.131:164.041-028.63

Cite this article as: Pypenko, I. S., \& Melnyk, Yu. B. (2021). Principles of digitalisation of the state economy. International Journal of Education and Science, 4(1), 42-50. https://doi.org/10.26697/ijes.2021.1.5

(C) 2021 Pypenko I. S., Melnyk Yu. B.

Published by Archives of International Journal of Education and Science

Open Access under a Creative Commons "Attribution" 4.0 Worldwide 


\section{Introduction}

The digitalisation of the world economy as a means of improving the quality of human life is becoming increasingly important on the agendas of politicians and economists. "Digitization of everything" is becoming a trend and a hallmark of the promises of these officials to expand the rights and opportunities of individuals and legal entities, businesses, various industries and more.

However, a foundation is needed to implement these promises and plans. This is where problems arise both theoretically - today there is no single definition of the digital economy, there are no guiding principles for digitalisation of the economy, etc., and in practice - in most countries there is no financial, legal, organizational and other regulation of this activity.

As a result, it is difficult to determine general global trends and prospects for the digitalisation of the economy for the development of a particular country and even a particular industry.

The aim of the study. To explore the current trends for digitalisation of the world economy and on this basis to develop principles and ways to implement them at the state level. This aim is specified in the following tasks: - to study the current state of digitalisation of the world economy;

- to clarify the essence of the concept "digital economy";

- to substantiate the guiding principles for digitalisation of the economy and ways of their implementation in Ukraine.

\section{Materials and Methods \\ A set of theoretical methods was used in the study: analysis of academic literature and current normative documents and draft legislative acts, as well as synthesis, comparison, generalization, systematization to define and substantiate the guiding principles for digitalisation of the economy and ways to implement them in Ukraine.}

\section{Results and Discussion}

The information age, which was characterized by the rapid development of data streams containing information about ideas and innovations, has logically become the basis for the development of the digital age of mankind.

Developed countries have begun the process of digitizing their industries, primarily economic. This was a requirement of the time, potentially ensuring the rapid development of their economy, dominated by technology, digital platforms, artificial intelligence, etc. In addition, digitalisation has started to change the social vision of the world. It should be noted that digitalisation is mainly seen as a positive characteristic of society development.

The World Bank in "World development report 2016: Digital dividends" (2016) notes the following positive trends in the digital economy:

1) boosting labor productivity;

2) increasing the competitiveness of companies;
3) reduction of production costs;

4) job creation (and new professions);

5) overcoming poverty and social inequality.

However, many scientists point out not only the benefits of digitalisation, but also emphasize a number of problems related to the global digitalisation of society.

Antikainen, Uusitalo, \& Kivikytö-Reponen (2018) point out that the digitalisation of the economy contributes to a more rational management of resources, and at the same time question whether human rights to privacy and anonymity can be violated. Among the advantages of the digital economy, Heavin and Power (2018); Rachinger et al. (2019) highlight the possibility of optimizing business management models and structural change, but recognize the complexity of state institutions of development and relations based on modern digital technologies, because it causes an exponential increase in data streams.

Latos et al. (2018) note that digitalisation complicates technological processes, but accelerates innovation cycles.

Among the benefits of digitalisation, Srai and Lorentz (2019) point to its ability to improve supply chain management.

Paritala et al. (2017) emphasize that due to digitalisation, modern production becomes more individual (the ability to develop a product according to the requirements of each customer).

Examining the problems and prospects of digitalisation in Europe and the United States, Abou-foul et al. (2020) note that empirical data indicate that the digitalisation of manufacturing companies has had a direct positive impact on the financial results of these companies.

Mazurchenko and Maršíková (2019) note the importance of digitalisation for human resources and the growing demand for digital skills in recent years.

Neubert (2018) emphasizes the internationalization of startups and various industries made possible by digitalisation.

According to Alcácer and Cruz-Machado (2019), the advantage of digitalisation is to ensure the creation of industrial ecosystems.

Exploring the implementation of digital technologies, Gruber (2017) emphasizes that they are a unique goal of industrial policy, and the inability to solve this problem can have a variety of economic consequences, as the digital economy consists of markets based on digital technologies.

Balcerzak and Pietrzak (2017) argue that the expansion of the digital sector has been a key factor in economic growth in recent years, and the transition to the digital world has affected a society that goes far beyond the context of digital technology alone.

Fuchs (2020), exploring an understanding of past perspectives, sheds light on current debates, revealing utopian notions of technical feasibility as well as antiutopian scenarios of social polarization and spatial inequality. This author emphasizes that digitalisation 
has long been perceived as a driving force in the labor market, social sphere and political arena.

Muro et al. (2017) note "despite much evidence that big changes are underway, surprisingly little data exist to track the spread of digital adoption across industries and into workplaces. In the absence of such information, the digitalization trend, as prominent as it is, remains diffuse and hard to pin down".

However, at the present stage of development of digitalisation of the economic sector in developed countries, we are able in some way to assess its advantages and disadvantages, as well as determine the prospects for its implementation in the economy of Ukraine.

So, first of all, we consider the genesis of the term "digital economy" and the understanding of the essence of this concept among researchers and practitioners.

Since the end of the last century, the term "digital economy" has been used in scientific circulation.

The term "digital economy", which we found in the literature, first appeared in scientific circulation in 1989 (Costello, 1989).

In 1991, Michie (1991) explored the large-scale economic and political shifts on the eve of the 1990s the globalization of markets and production and the development of the digital economy.

In 1995, Tapscott (1995) published a book directly focused on the phenomenon of the digital economy: "The digital economy: Promise and peril in the age of networked intelligence".

In the same year, Negroponte (1995) in his book "Being Digital" predicts that "the transition from atoms to bits is irreversible and unstoppable".

Lane (1999) emphasizes "the digital economy is now a major driver of economic growth and social change".

In 2000, the book "Understanding the digital economy: data, tools, and research" was published (Brynjolfsson $\&$ Kahin, 2000). This book is the first to analyze the economic implications of the Internet and e-commerce in the United States and abroad, and to consider new types of data collection and research that can be done by public and private organizations. The aim of the study was to assess the current state of the digital economy, to promote a better understanding of the growth and socio-economic consequences of information technology and e-commerce. Brynjolfsson and Kahin (2000) say that to assess the impact of IT on the digitalisation of the economy, it is necessary to take into account changes in the following five areas:

1) IT infrastructure;

2) e-commerce;

3) firm and industry organization;

4) demographic and labor market characteristics of individuals using IT;

5) price behavior.

In 2001, Mesenbourg and Atrostic (2001), exploring individual strategies for measuring the US digital economy, identified three main components of the digital economy:

- infrastructure support;

- e-business processes (how business is conducted);
- e-commerce transactions (sale of goods and services on the Internet).

Mesenbourg and Atrostic (2001) point out that ebusiness processes and e-commerce operations rely on computer networks. "This dependence on computer networks and the benefits they can provide is the main difference between e-commerce and other businesses". Thus, information technology and computer networks have become the basis for the emergence of a new phenomenon - the digital economy.

Okhrimenko et al. (2019) note that the concepts of "digital technology" and "digital economy" were introduced into the academic vocabulary due to technological changes in the 21 st century regarding the "merger" of telecommunications, information and communication technologies and innovations.

Brennen and Kreiss (2016), exploring the origins of the concept of "digitalisation", note that it is closely related to the concept of "digitisation". In the literature, these two terms are used interchangeably. However, each of them has analytical value and difference. In particular, digitisation is a material process of converting analog streams of information into digital bits, while digitalisation is a way to restructure many areas of social life around digital communications and media infrastructure.

Gasanov G. and Gasanov T. (2017) define the digital economy as "a system of institutional categories in the economy, based on advanced scientific achievements and advanced technologies, first of all, on digital information and communication technologies, the functioning of which is created to increase the efficiency of social production, ensuring sustainable economic growth by improving the welfare and quality of life of the population".

Richter et al. (2017) suggest the five main attributes of the digital economy: digitized and tracked, connected, shared, personalized and direct.

Antikainen et al. (2018) characterize digitalisation as an integral component of the modern world economy, which contributes to a more rational management of resources.

Thus, the concept of "digital economy" is closely related to such concepts as "digital technology", "digitalisation", "digitisation" and others, but has its own specific features and is characterized by its own indicators. Under these conditions, there is a critical need to clarify the essence of the concept of "digital economy".

The study of the genesis of the term "digital economy" and the essence of understanding this concept by scientists in various fields allowed us to clarify it.

Digital economy is a type of economic activity in the system of socio-behavioral and cultural relations with the use of digital technologies, characterized by the creation, collection, processing, storage, transfer and use of digitized resources.

Today it is impossible to imagine the economic activity of any state without the use of digitized resources: from the regulatory and legal framework to the provision of online services, e-payment, e-commerce and more. 
Kraus et al. (2018) rightly note that the following digital technologies, products and services are becoming commonplace, which yesterday were considered innovative trends in today's socio-economic environment: BioTech, NanoTech, RetailTech, FinTech, LegalTech, InsurTech, GovTech, BlockChain, Digital Marketing, CRM\&BPM, Grid Technology, Digital Insurance, ePrescription.

The rapid development of the digital economy around the world requires the development of new concepts and categorical apparatus. The researchers have introduced new terms and concepts, among them: a digital product is an information service and the result of work, presented in digital format, written in binary code (Pypenko, 2019), digital asset is an information resource derivative of the right to a value and circulating in the distributed ledger in the form of a unique identifier (Kud, 2019), etc.

It should be noted that Ukraine has already begun to take important steps towards digitalisation of the country's economy (Cabinet of Ministers of Ukraine, 2018): the Ministry and the Committee for Digital Transformation of Ukraine were created, e-document circulation in government agencies, administrations, courts was introduced, etc.

An important and necessary step in regulating the transition to the digital economy of Ukraine was the development and consideration by the relevant committees of the Verkhovna Rada of Ukraine of draft laws: No. 4303, 2020/11/02, "On Stimulating the Development of the Digital Economy in Ukraine" (The main legal portal of Ukraine, 2020, November 2), No. 4328, 2020/11/05, "On Tokenized Assets and Cryptocurrencies" (The main legal portal of Ukraine, 2020, November 5), etc.

The next important step is to define the guiding principles for digitalisation of the state economy.

Periodicals and the Internet contain publications that supposedly announced the development or review of existing principles of the digital economy.

As an example, consider a few of these publications.

Plotnikov (2018) in the paper entitled "Basic Principles of the Concept of Digital Economy" states that he provides an overview of the principles of the digital economy: digitized information, hypertrophied growth in profitability, new models of industrial production. However, this paper does not contain a substantiation of these principles, their necessity and sufficiency are not defined, sometimes there is no logical connection between them, the ways of realization of these principles are not specified.

Krasnova (2018) in the publication entitled "10 Public Principles of the Digital Economy" recommends to ministries, administrations and other institutions her own vision of the principles of the digital economy. However, Krasnova (2018) does not cite any specific principles, moreover, replaces or confuses them with the problem, purpose, objectives, indicators, sources of funding and so on. This publication is populist and has nothing to do with the principles of the digital economy.
Batrakova and Lynovetska (2018), despite the title of their paper "Features and Principles of the Digital Economy in Ukraine", which is directly related to the principles of the digital economy, do not cite any of the principles.

The authors of the paper "Fairness and the Arm's Length Principle in a Digital Economy" (Greil et al., 2018) abstracted only on one of the principles of the digital economy. We agree with these authors and believe that this principle is undoubtedly important, but, in our opinion, it should be implemented comprehensively with others, otherwise it is difficult to predict the effectiveness of such activities, even in the implementation of this principle.

Riznyk (2019) in his abstract "Principles of Digitalisation of Ukraine's Economy" offers the following principles: accessibility, standardization, information security, integration, competitiveness, innovation. Unfortunately, the volume of this publication (one-page abstract in the conference materials) does not give us an understanding of what the author proceeded from when choosing these principles, and how exactly they should be implemented in Ukraine. However, this publication shows that the problem of substantiating the principles for digitalisation of the economy is relevant in the scientific circles of Ukraine and needs its further development.

A number of documents and publications, where various principles of digitisation have been proposed, deserve attention: provide services based on customers' needs, cut unnecessary red tape, build easy-to-use and secure services, produce benefits for our customers quickly, serve in case of disruptions, ask for new information only once, make full use of the existing public and private online services, provide open data, open access to information and open interfaces for businesses and citizens, designate an owner for every service and its implementation (Ministry of Finance of Finland, 2016), start with a transformative vision, focus on building digital customer engagement, support the vision with secure digital platforms, drive insight with data-driven visualization, embrace digital agility to create advantage (CohnReznick LLP, 2015). Various aspects of the digitalisation process in the public sector are considered in the following works: Bountouri (2017); Chattell (1998); CohnReznick LLP (2015); Ministry of Finance of Finland (2016); UNESCO (n.d.).

However, today in the literature there is no reasonable system or set of principles and according to them ways of practical implementation, which could be guided in the process of digitalisation of the country's economy.

The analysis of the advantages and disadvantages of the practice of digitalisation of the economy in the countries of the world with high economic development, as well as our study allowed to substantiate the guiding principles for digitalisation of the economy: integrity, phasing, leading, innovation, adaptability, simplicity (accessibility). 
Ways of implementation that will ensure, in our opinion, the effectiveness of digitalisation of the economy, are proposed for each of the defined principles. It should be noted that the ways of implementing the above principles may have certain features of their implementation in different countries and even industries (Figure 1).

\section{Figure 1}

The Guiding Principles for Digitalisation of the Economy

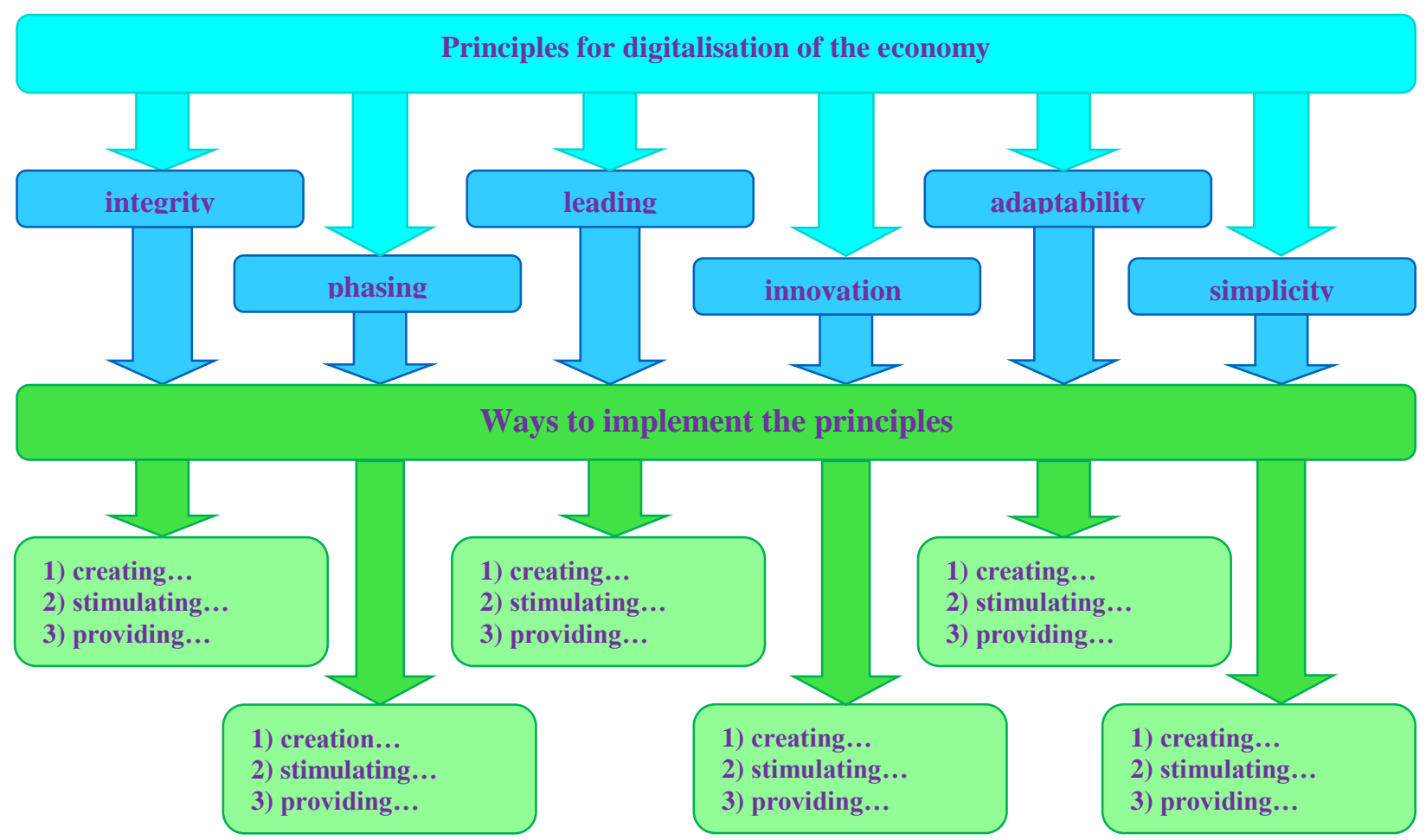

We characterize each of these principles, as well as ways to implement them in accordance with the realities of Ukraine.

1. The principle of integrity involves the digitalisation of the economy on the basis of internal unity and interconnection of all parts of digital systems into a single whole.

Ways to implement:

- creating strong internal connections of systems in comparison with external connections and their impact; - stimulating the development of all parts of the digital systems of the state;

- ensuring a certain autonomy of information systems of the state.

2. The principle of phasing involves the digitalisation of the economy on the basis of a purposeful and organized digitalisation process, which highlights the various stages, characterized by their goals, objectives, content, methods and forms of activity.

Ways to implement:

- creating the legal framework for the digital economy of the state;

- stimulating the development of national startups, projects and state digitalisation programs;

- providing state support and approval of policy documents on the implementation of the digital economy in the country.

3. The principle of leading involves the digitalisation of the economy based on the management of the digitalisation process to ensure the managed transfer of the economic system at all stages to a higher quality level.

Ways to implement:

- creating an organizational structure (ministries, institutional and departmental units) for the digitalisation of the state economy;

- stimulating the training and retraining of specialists in the field of digital economy in the country;

- staffing and providing modern programs (use of cross-functional commands and analytics, etc.).

4. The principle of innovation involves the digitalisation of the economy on the basis of introduction of advanced digital technologies, as well as support for science and education of the state in the field of research and development of new digital products.

Ways to implement:

- creating conditions for the study, development and innovation development for citizens in the state;

- stimulating the development of innovations that meet the needs of consumers in the country and are competitive in the international market (introduction of Robotic Process Automation, smart technologies, etc.); - providing and supporting new digital technologies at the state level.

5. The principle of adaptability involves the digitalisation of the economy based on the use of flexible digital technologies and software products that 
can be quickly upgraded, adapt to new conditions and factors influencing the external and internal environments.

Ways to implement:

- creating flexible digital technologies and software products that can be used both at national and international levels;

- stimulating the development and implementation of innovations that take into account current trends and changes (Agile-marketing, artificial intelligence, etc.); - providing support for innovations in the state at all stages from the author's ideas to their commercialization.

6. The principle of simplicity (accessibility) involves the digitalisation of the economy based on the use of simple (uncomplicated) in the use of digital technologies, which are mostly mobile and have a low price.

\section{Ways to implement:}

- creating favorable conditions for providers that provide high-quality Internet access in the country for a small price;

- stimulating and assisting the state to all persons (individuals and legal entities) in digitisation of documentation and other information that facilitates access to services and minimizes efforts, as well as helps to improve the living standards of the population; - providing free and inexpensive access to $\mathrm{WiFi}$ for the entire population of the state.

We believe that taking into account the specifics of digitalisation of Ukraine, the principles defined by us and the proposed ways of their implementation are necessary and sufficient for effective digitalisation of the country's economy.

The introduction of digital technologies and digitalisation of the economy in Ukraine will accelerate the processes of transformation of relations between participants in various sectors, such as economics, energy, transport, security, education, health care, trade, etc.

The obtained results complement our previous research (Kud, Mashchenko, \& Pypenko, 2020; Kud \& Pypenko, 2018; Melnyk, 2019; Pypenko, 2020; Pypenko \& Kud, 2019; Pypenko \& Melnyk, 2020a; Pypenko \& Melnyk, 2020b) and expand the conclusions of many studies (Abou-Foul et al., 2020; Antikainen et al., 2018; Brennen \& Kreiss, 2016; Brynjolfsson \& Kahin, 2000; Cantoni \& Mangia, 2019; Richter et al., 2017; Kagermann, 2015; Lane, 1999; Mazzone, 2014).

\footnotetext{
Conclusions

Under the impact of various factors and innovations in the field of information technology, a new economic phenomenon - the digital economy - was born.

The results of our study showed that the use of the term and the introduction of the concept "digital economy" is a natural trend in the development of economic theory and practice, based on various factors, and above all, the development of IT.

The study of the genesis of the digital economy and the analysis of the concepts and features proposed by
}

scientists allowed us to clarify the essence of this concept.

We propose to understand the digital economy as a type of economic activity in the system of sociobehavioral and cultural relations with the use of digital technologies, characterized by the creation, collection, processing, storage, transfer and use of digitized resources.

This paper reveals the current trends of digitalisation of the world economy and provides responsible persons, who determine the country policy, the guiding principles for defining and implementing digitalisation strategies in the most appropriate sectors of the economy in Ukraine.

In our opinion, the guiding principles for digitalisation of the economy should be: integrity, phasing, leading, innovation, adaptability, simplicity (accessibility). Ways of implementation were developed for each principle. They contain answers to key questions: what needs to be done? how to stimulate? what support should be provided by the state?

In this paper, we do not claim an exhaustive list of principles for digitalisation of the state economy and ways to implement them. However, we consider them necessary and sufficient to take into account the peculiarities of digitalisation, as well as to determine the preconditions and possible positive consequences for the effective digitalisation of Ukraine's economy.

Thus, the digitalisation of the Ukrainian economy, based on the experience of digitalisation of the economic sector of developed countries and taking into account national and subnational characteristics, will help solve a number of economic and social problems, including reducing the digital divide between different social groups and people of different ages; improving the quality of life of the population; stimulating the development and implementation of own information technologies, communication, etc.

\section{Funding Source}

This research received no specific grant from any funding agency in the public, commercial, or not-forprofit sectors. The research was conducted on the basis of the Scientific Research Institute KRPOCH.

\section{Conflicts of Interests}

The authors declare that there is no conflict of interests.

\section{References}

Abou-Foul, M., Ruiz-Alba, J. L., \& Soares, A. (2020). The impact of digitalization and servitization on the financial performance of a firm: an empirical analysis. Production Planning \& Control. https://doi.org/10.1080/09537287.2020.1780508

Alcácer, V., \& Cruz-Machado, V. (2019). Scanning the industry 4.0: A literature review on technologies for manufacturing systems. Engineering Science and Technology, an International Journal, 22(3), 889-919. https://doi.org/10.1016/j.jestch.2019.01.006

Antikainen, M., Uusitalo, T., \& Kivikytö-Reponen, P. (2018). Digitalisation as an enabler of circular 
economy. Procedia CIRP, 73, 45-49. https://doi.org/10.1016/j.procir.2018.04.027

Balcerzak, P. A., \& Pietrzak, B. M. (2017). Digital economy in Visegrad countries. Multiplecriteria decision analysis at regional level in the years 2012 and 2015. Journal of Competitiveness, $\quad 9(2), \quad 5-18$. https://doi.org/10.7441/joc.2017.02.01

Batrakova, T. I., \& Lynovetska, V. Yu. (2018). Osoblyvosti ta pryntsypy tsyfrovoi ekonomiky v Ukraini [Peculiarities and principles of digital economy in Ukraine]. Ekonomichni studii Economic Studies, 2(20), 94-97. [in Ukrainian]

Bountouri, L. (2017). Digitization. In L. Bountouri (Ed.), Archives in the digital age (pp. 29-36). Chandos https://doi.org/10.1016/B978-1-84334-7774.00003-7

Brennen, J. S., \& Kreiss, D. (2016). Digitalization. In K. B. Jensen, E. W. Rothenbuhler, J. D. Pooley, \& R. T. Craig (Eds.), The International Encyclopedia of Communication Theory and Philosophy. Wiley. https://doi.org/10.1002/9781118766804.wbiect1 11

Brynjolfsson, E., \& Kahin, B. (2000). Understanding the digital economy: Data, tools, and research. The MIT Press. https://doi.org/10.7551/mitpress/6986.001.0001

Cabinet of Ministers of Ukraine. (2018). Pro skhvalennia Kontseptsii rozvytku tsyfrovoi ekonomiky ta suspilstva Ukrainy na 2018-2020 roky ta zatverdzhennia planu zakhodiv shchodo yii realizatsii [On approval of the Concept of development of the digital economy and society of Ukraine for 2018-2020 and approval of the action plan for its implementation] (No. 67-p). Governmental Courier. https://zakon.rada.gov.ua/laws/show/67-2018$\%$ D1\%80\#Text [in Ukrainian]

Cantoni, F., \& Mangia, G. (2019). Human resource management and digitalization. Routledge. https://doi.org/10.4324/9780429425288

Chattell, A. (1998). Creating value in the digital era. London: Palgrave Macmillan. https://doi.org/10.1007/978-1-349-14711-3_2

CohnReznick LLP. (2015). Digital transformation: Leading success at growth companies. https://www.cohnreznick.com/insights/fiveprinciples-digital-transformation

Costello, N. (1989). Planning the digital economy. Kaldor Memorial Lectures.

Fuchs, M. (2020). Does the digitalization of manufacturing boost a 'Smart' era of capital accumulation? De Gruyter, 64(2), 47-57. https://doi.org/10.1515/zfw-2019-0012

Gasanov, G. A., \& Gasanov, T. A. (2017). Cifrovaja jekonomika kak novoe napravlenie jekonomicheskoj teorii [Digital economy as a new direction of economic theory]. Regionalnye problemy preobrazovanija jekonomiki Regional Problems of Economic
Transformation,

6 , 10 [in Russian]

Greil, S., Schwarz, Ch., \& Stein, S. (2018). Fairness and the arm's length principle in a digital economy. Düsseldorf Working Papers in Applied Management and Economics, 42. http://dx.doi.org/10.2139/ssrn.3209205

Gruber, H. (2017). Innovation, skills and investment: a digital industrial policy for Europe. Economia $e$ Politica Industriale: Journal of Industrial and Business Economics, 44(3), 327-343. https://doi.org/10.1007/s40812-017-0073-x

Heavin, C., \& Power, D. J. (2018). Challenges for digital transformation - towards a conceptual decision support guide for managers. Journal of Decision Systems, 27(Sup. 1), 38-45. https://doi.org/10.1080/12460125.2018.1468697

Kagermann, H. (2015). Change through digitizationvalue creation in the age of industry 4.0. In H. Albach, H. Meffert, A. Pinkwart, \& R. Reichwald (Eds.), Management of Permanent Change (pp. 23-45). Springer Gabler. https://doi.org/10.1007/978-3-65805014-6_2

Krasnova, A. (2018). 10 publichnyh principov Cifrovoj jekonomiki [10 public principles of the Digital economy]. Strategy 24. https://strategy24.ru/rf/news/10-publichnykhprintsipov-tsifrovoy-ekonomiki [in Russian]

Kraus, N. M., Holoborodko, O. P., \& Kraus, K. M. (2018). Tsyfrova ekonomika: trendy ta perspektyvy avanhardnoho kharakteru rozvytku [Digital economy: trends and prospects of the avant-garde change of development]. Efektyvna ekonomika - Efficient Economy, 1 . http://www.economy.nayka.com.ua/pdf/1_2018/ 8.pdf [in Ukrainian]

Kud, A. A., Mashchenko, M. A., \& Pypenko, I. S. (2020). Predicting the impact of digital assets on socioeconomic development of an enterprise. $\mathrm{KRPOCH}$. https://doi.org/10.26697/9786177089116.2020

Kud, A., \& Pypenko, I. S. (2018). Social and economic foundation of the implementation of blockchainbased systems of digital assets in developing countries. International Journal of Education and $\quad$ Science, 30. https://doi.org/10.26697/ijes.2018.3-4.30

Kud, A. A. (2019). Substantiation of the term "digital asset": economic and legal aspects. International Journal of Education and Science, 2(1), $\quad$ 41-52. https://doi.org/10.26697/ijes.2019.1.06

Lane, N. (1999). Advancing the digital economy into the 21 st century. Information Systems Frontiers, 1 , https://doi.org/10.1023/A:1010010630396

Latos, B. A., Harlacher, M., Burgert, F., Nitsch, V., Przybysz, Ph., \& Mütze-Niewöhner, S. (2018). Complexity drivers in digitalized work systems: implications for cooperative forms of work. 
Advances in Science, Technology and Engineering Systems Journal, 3(5), 171-185. https://doi.org/10.25046/aj030522

Mazzone, D. M. (2014). Digital or death: Digital transformation - The only choice for business to survive smash and counter. Mississauga: Smashbox Consulting.

Mazurchenko, A., \& Maršíková, K. (2019). Digitallypowered human resource management: skills and roles in the digital era. Acta Informatica Pragensia, $\quad 8(2), \quad 72-87$. https://doi.org/10.18267/j.aip.125

Melnyk, Yu. B. (2019). Cryptocurrency possibilities in target financing of public social payments. International Journal of Education and Science, 2(2), 55. https://doi.org/10.26697/ijes.2019.2.40

Mesenbourg, T. L., \& Atrostic, B. K. (2001). Measuring the U.S. digital economy: theory and practice. https://2001.isiproceedings.org/pdf/1074.PDF

Michie, J. (1991). The economics of restructuring and intervention.

https://econpapers.repec.org/bookchap/elgeeboo $\mathrm{k} / 312 . \mathrm{htm}$

Ministry of Finance of Finland. (2016). Principles of digitalisation. https://vm.fi/en/principles-ofdigitalisation

Muro, M., Sifan, L., Whiton, J., \& Kulkarni, S. (2017). Digitalization and the American Workforce. Brookings India. https://hdl.handle.net/11540/7892

Negroponte, N. (1995). Being digital. London: Hodder \& Stoughton. https://governance40.com/wpcontent/uploads/2018/12/Nicholas-NegroponteBeing-Digital-Vintage-1996.pdf

Neubert, M. (2018). The impact of digitalization on the speed of internationalization of lean global startups. Technology Innovation Management Review, 8(5), 44-54. https://doi.org/10.22215/timreview/1158

Okhrimenko, I., Sovik, I., Pyankova, S., \& Lukyanova, A. (2019). Digital transformation of the socio-economic system: prospects for digitalization in society. Revista ESPACIOS, 40(38),

26-34. https://www.revistaespacios.com/a19v40n38/19 403826.html

Paritala, P. K., Manchikatla, S., \& Yarlagadda, P. K. (2017). Digital manufacturing-applications past, current, and future trends. Procedia Engineering, $\quad 174, \quad 982-991$. https://doi.org/10.1016/j.proeng.2017.01.250

Plotnikov, A. V. (2018). Osnovnye principy koncepcii cifrovoj jekonomiki [Basic principles of the digital economy concept]. Moskovskij jekonomicheskij zhurnal - Moscow Economic Journal, 5(2), 330-335. https://doi.org/10.24411/2413-046x-2018-15069 [in Russian]

Pypenko, I. S. (2020). Classification of the criteria for cryptocurrencies. In V.S. Ponomarenko (Ed.), Ekonomichnyi rozvytok $i$ spadshchyna Semena
Kuznetsia - Simon Kuznets Cycles Economic Development (pp. 228-229). Helvetyka.

Pypenko, I. S. (2019). Digital product: the essence of the concept and scopes. International Journal of Education and Science, 2(4), 56. https://doi.org/10.26697/ijes.2019.4.41

Pypenko, I. S., \& Kud, A. A. (2019). Genesis of IT economy: from cryptocurrency to digital asset. International Journal of Education and Science, 2(2), 56. https://doi.org/10.26697/ijes.2019.2.41

Pypenko, I. S., \& Melnyk, Yu. B. (2020). Creating a business ecosystem based on blockchain technology. International Journal of Education and Science, $3(4), \quad 53$. https://doi.org/10.26697/ijes.2020.4.26

Pypenko, I. S., \& Melnyk, Yu. B. (2020). Systemnyi pidkhid do klasyfikatsii systemy kryteriiv kryptovaliut [Systems Approach to Classification of the Cryptocurrency Criteria System]. International Journal of Education and Science, 3(1), 30-40. https://doi.org/10.26697/ijes.2020.1.3 [in Ukrainian]

Rachinger, M., Rauter, R., Müller, C., Vorraber, W., \& Schirgi, E. (2019). Digitalization and its influence on business model innovation. Journal of Manufacturing Technology Management, $\quad 30(8), \quad 1143-1160$. https://doi.org/10.1108/JMTM-01-2018-0020

Richter, C., Kraus, S., Brem, A., Durst, S., \& Giselbrecht, C. (2017). Digital entrepreneurship: Innovative business models for the sharing economy. Creativity and Innovation Management, 26(3), 300-310. https://doi.org/10.1111/caim.12227

Riznyk, N. M. (2019). Pryntsypy tsyfrovizatsii ekonomiky Ukrainy [Principles of digitization of the Ukrainian economy]. In R. M. Rohatynskyi (Ed.), Innovatsii: aspekty upravlinnia, vyrobnytstva, sfery obsluhovuvannia - Innovations: Aspects of Management, Production, Service Sphere (p. 70). TNTU. http://elartu.tntu.edu.ua/bitstream/lib/28232/2/I AYVSO_2019_Riznyk_N_M-

Principles_of_digitization_70.pdf [in Ukrainian]

Srai, J. S., \& Lorentz, V. (2019). Developing design principles for the digitalisation of purchasing and supply management. Journal of Purchasing and Supply Management, 25(1), 78-98. https://doi.org/10.1016/j.pursup.2018.07.001

Tapscott, D. (1995). The digital economy: Promise and peril in the age of networked intelligence. McGrawHill Companies.

The main legal portal of Ukraine. (2020, November 2). Proekt Zakonu Ukrainy "Pro stymuliuvannia rozvytku tsyfrovoi ekonomiky v Ukraini” [The Draft Law of Ukraine "On stimulating the development of the digital economy in Ukraine"].

http://w1.c1.rada.gov.ua/pls/zweb2/webproc4_1 ?pf3511=70298 [in Ukrainian] 
The main legal portal of Ukraine. (2020, November 5). Proekt Zakonu Ukrainy "Pro tokenizovani aktyvy ta kryptoaktyvy" [The Draft Law of Ukraine "On tokenized assets and cryptocurrencies"].

https://w1.c1.rada.gov.ua/pls/zweb2/webproc4_ 1?pf3511=70353 [in Ukrainian]
UNESCO (n.d.). Fundamental principles of digitization of documentary heritage. http://www.unesco.org/new/fileadmin/MULTI MEDIA/HQ/CI/CI/pdf/mow/digitization_guidel ines_for_web.pdf

World Bank. (2016). World development report 2016: Digital dividends. Washington, DC:World Bank https://doi.org/10.1596/978-1-4648-0671-1

\begin{abstract}
Анотація
Вступ: Цифровізація світової економіки як засіб підвищення якості життєдіяльності людини набуває все більшого значення. Сутність изифрової економіки є багатогранною і недостатньою дослідженою, зокрема потребує уточнення поняття “ицфрова економіка”, потребують обтрунтування принциии иุифровізації економіки для конкретних країн та шляхи їх реалізації.

Мета: Дослідити сучасні тенденції цифрровізації світової економіки та на цььому підтрунті розробити принципи та шляхи їх реалізації на державному рівні.

Матеріали і Методи: Використано комплекс теоретичних методів: аналіз наукової літератури, сучасних нормативних документів $і$ проєктів законодавчих актів, а також синтез, порівняння, узагальнення, систематизація щуодо визначення та обтрунтування керівних принциипів циифровізації економіки та шляхи їх реалізації в Україні.

Результати: Досліджено сучасні тенденції цุифровізації світової економіки. Уточнено сутність поняття “иифрова економіка", котру розуміємо, як вид економічної діяльності в системі соціально-поведінкових $i$ культурних відносин з використанням цифрових технологій, щуо характеризується створенням, збором, обробкою, зберіганням, передачею та використанням оцифрованих ресурсів. Обтрунтовано керівні принципи циифровізаціі економіки: изілісність, поетапність, керованість, інноваційність, адаптивність, простота (доступність). До кожного принципу розроблені иляхи реалізащії, в яких містяться відповіді на ключові питання: щуо треба зробити? як стимулювати? яке забезпечення має бути з боку держави?

Висновки: Ця робота розкриває сучасні тенденції циифровізації світової економіки і надає відповідальним особам, щзо визначають політику в країні, керівні принципи для визначення та реалізації стратегій цүифровізаиії в найбільш підходящих областях економіки на державному рівні.
\end{abstract}

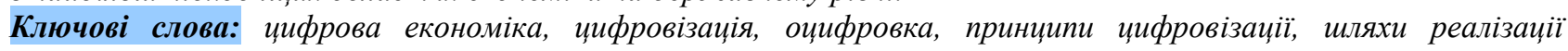
принципів.

\title{
Аннотация
}

Введение: Цифровизаџия мировой экономики как средство повышения качества жизнедеятельности человека приобретает все большее значение. Сущцость цифровой экономики является многогранной и недостаточно исследованной, в частности требует уточнения понятие “иифровая экономика”, требуют обоснования принципы цุифровизации экономики для конкретных стран и пути их реализации.

Цель: Исследовать современнье тенденции цุифровизаџии мировой экономики и на этой основе разработать принщипы и пути их реализации на государственном уровне.

Материаль и Методы: Использован комплекс теоретических методов: анализ научной литературы, современных нормативных документов и проектов законодательных актов, а также синтез, сравнение, обобщение, систематизация по определению и обоснованию руководящих принципов цүифровизации экономики и путей их реализации в Украине.

Результаты: Исследованы современные тенденции циирровизации мировой экономики. Уточнена сущность понятия “иифровая экономика", которую понимаем, как вид экономической деятельности в системе социально-поведенческих и культурных отношений с использованием иифровых технологий, что характеризуется созданием, сбором, обработкой, хранением, передачей и использованием оцифрованных ресурсов. Обосновань руководящие принципь цифровизации экономики: целостность, поэтапность, управляемость, инновационность, адаптивность, простота (доступность). $K$ каждому принцииу разработаны пути реализачии, в которых содержатся ответы на ключевые вопросы: что надо сделать? как стимулировать? какое обеспечение должно быть со стороны государства?

Выводы: Эта работа раскрывает современные тенденциии иңифровизации мировой экономики и предоставляет ответственным лицам, определяющие политику в стране, руководящие принципь для определения и реализациии стратегий ичифровизаџии в наиболее подходящих областях экономики на государственном уровне.

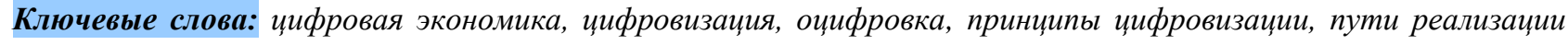
принциипов.

The electronic version of this article is complete. It can be found online in the IJES Archive
https://ijes.culturehealth.org/en/archive and $\begin{aligned} & \text { in } \\ & \text { https://ekrpoch.culturehealth.org/handle/lib/58 }\end{aligned}$

